\title{
Farklı Diyet Modellerinin Bağırsak Mikrobiyotası Üzerine Etkisi
}

\author{
The Effect of Different Diet Models on Gut Microbiota
}

\author{
Feride Ayyıldız ${ }^{1}$, Hilal Yıldıran ${ }^{2}$
}

Geliş tarihi/Received: 12.07.2019 • Kabul tarihi/Accepted: 29.08.2019

\section{ÖZET}

Son dönemde popüler bir konu haline gelen bağırsak mikrobiyotası günümüzde vücudun bir organı olarak tanımlanmaktadır. Yaş, genetik, beslenme, fiziksel aktivite gibi birçok faktör bağırsak mikrobiyotasını etkilemektedir. Bu faktörlerin başında gelen diyet, faydalı veya zararlı bakteri türlerinin sayısına ve çeşitliliğine etki etmektedir. Akdeniz diyeti, vejetaryen diyet, glutensiz diyet, yüksek proteinli diyet, Paleo diyet, düşük karbonhidrat içeren diyet, açlık diyetleri gibi farklı diyet modelleri bulunmaktadır. Bu diyet modelleri bakteri sayısı ve çeşitliliğinin yanı sıra, bakteri metabolitlerini, inflamasyon göstergelerini, bağırsak geçirgenliğini, oksidatif stresi, bağırsak homeostazı ve disbiyozisine etki ederek organizmayı etkilemektedir. Bu derlemede farklı diyet modellerinin bağırsak mikrobiyotası üzerine olası etkisi irdelenmiştir.

Anahtar Kelimeler: Mikrobiyota, diyet modelleri, bakteri türleri

\begin{abstract}
Gut microbiota, which has recently become a popular topic, is now described as an organ of the body. Many factors such as age, genetics, nutrition, physical activity affect gut microbiota. Diet, as the leading factor, affect the number and diversity of beneficial or harmful bacterial species. There are different diet models such as Mediterranean diet, vegetarian diet, gluten free diet, high protein diet, Paleo diet, low carbohydrate diet, fasting diets. These diet models have an impact on the organism by influencing bacterial metabolites, inflammation indicators, intestinal permeability, oxidative stress, gut homeostasis and dysbiosis, as well as number and diversity of bacteria. In this review, the possible effects of different diet models on the gut microbiota are discussed.
\end{abstract}

Keywords: Microbiota, diet models, bacterial species

\section{GíRIŞ}

Bağırsak mikrobiyotası en az 1000'den fazla bakteri türünü içeren, karbonhidrat sindirimi, zararlı mikroorganizmaların baskılanması, vitamin sentezi, immün sistem aktivitesi ve ilaç metabolizması gibi birçok hayati fonksiyonda görev alan bir organ olarak tanımlanmaktadır. Batı tarzı diyet, sedanter yaşam,

1. İletişim/Correspondence: Gazi Üniversitesi Sağlık Bilimleri Fakültesi Beslenme ve Diyetetik Bölümü, Ankara, Türkiye - E-posta: feridecelebi_dyt@hotmail.com (1) https://orcid.org/0000-0003-2828-3850 sigara vealkolkullanımıgibibazıfaktörler bağırsaktaki mikrobiyal çeşitliliği etkileyerek birçok hastalıkla ilişkilendirilmektedir (1). Bağırsak mikrobiyotasını etkileyen en önemli faktörlerden biri diyettir. Bağırsak mikrobiyotasında bulunan Bacteroidetes, Firmicutes, Proteobacteria, Actinobacteria ve Verrucomicrobia

2. Gazi Üniversitesi Sağlık Bilimleri Fakültesi Beslenme ve Diyetetik Bölümü, Ankara, Türkiye

(1) https://orcid.org/0000-0001-7956-5087 
gibi bakteri türlerinin tür ve miktarında özellikle diyet gibi çevresel faktörlerin etkisiyle değişiklik oluşabilmektedir (2). Bağırsak mikrobiyotasındaki değişikliklerin \%12'sinden genetik faktörler sorumlu iken, \%57'sinden de diyetin sorumlu olduğu savunulmaktadır (3).

Besinlerin sindirimiyle oluşan metabolitler, konağın metabolizmasını etkilemektedir (4). Dolayısıyla diyette yapılan akut bir değişiklik- örneğin, tamamen hayvansal veya bitkisel kaynaklı beslenme sadece 24 saatte mikrobiyal kompozisyonu değiştirmektedir. Ancak bu kompozisyon diyetin sonlandırılmasından sonraki 48 saat içinde tekrar başlangıç durumuna dönmektedir (5). Diyet değişimlerinin neden olduğu kısa süreli değişikliklerin yanı sıra, bağırsak mikrobiyotasının kompozisyonu üzerine alışılmış diyetin uzun vadeli sonuçları bulunmaktadır (6). Son ylllarda glutensiz diyet, düşük karbonhidrat içeren diyetler, Paleo diyet gibi farklı diyet türlerinin popülaritesi artmıştır. $\mathrm{Bu}$ derlemede güncel literatür eşliğinde farklı diyet türlerinin bağırsak mikrobiyotasına etkisi açıklanmıştır.

\section{Akdeniz Diyeti}

Akdeniz diyeti, sağlık durumunun iyileştirilmesinin yanı sıra, kanser, metabolik sendrom, kardiyovasküler hastalıklar, tip 2 diyabet (Tip 2 DM) ve nörodejenaratif hastalıklar gibi bulaşıcı olmayan hastalıkların morbidite ve mortalite hızının azalmasında etkili bir diyet modelidir (2). Klasik Akdeniz diyeti; zeytinyağı, sebze, meyve, tam tahıl, kurubaklagil, yağlı tohum ve sert kabuklu meyve tüketiminin yüksek miktarda; balık ve süt ürünlerinin orta miktarda, et ve ürünlerinin ise düşük miktarda ve orta miktarda şarap tüketimini içermektedir (7). Bu diyetin yüksek miktarda posa, tekli ve çoklu doymamış yağ asitleri, antioksidanlar ve biyoaktif bileşikler içermesi nedeniyle sağlık üzerinde olumlu etki sağlayabileceği düşünülmektedir (8).

Akdeniz diyetinin mikrobiyota ile ilişkisinin sebze, meyve, tahıl (özellikle tam tahıl), sert kabuklu meyve ve kurubaklagil, doymamış yağ asidi (özellikle tekli doymamış yağ asidi) tüketiminden kaynaklı olduğu bildirilmiştir. Düşük doymuş yağ asidi ve yüksek tekli doymamış ile çoklu doymamış yağ asidi alımıyla inflamatuvar sinyal azalmaktadır (1). Diyette artan sebze, meyve ve tahıl tüketiminden dolayı fekal kısa zincirli yağ asidi (KZYA) (asetat, propiyonat ve bütirat) miktarında da artış görülmektedir (9). Bitkisel kaynaklı beslenme sadece Bifidobacterium ve Lactobacillus spp. üretimindeki artışla değil aynı zamanda özellikle bütirat ve metan üreten faydalı bakteri türlerinin büyümesinin düzenlenmesiyle de ilişkilidir (9). Bu diyetin vejetaryen, vegan ve alışılmış omnivor beslenmeye göre fekal KZYA'yı, Prevotella ve Firmicutes sayısını daha fazla artırdığı gözlemlenmiştir (10). Klasik Akdeniz diyetindeki farklı diyet bileşenlerinin mikrobiyota ve sağlıkla ilişkisi Tablo 1'de özetlenmiştir (8).

Yapılan bazı çalışmalarda Akdeniz diyetinde yer alan besin örüntüsünün obeziteyi, lipit profilini ve inflamasyonu iyileştirdiği gösterilmiştir (11,12). $\mathrm{Bu}$ değişikliklerin Lactobacillus, Bifidobacterium ve Prevotella seviyesindeki artış Clostridium'da azalışla ilişkili olabileceği bildirilmiştir (11,12). Nagpal et al. (8), Akdeniz diyetiyle mikrobiyom çeşitliliğinin ve Bacteroidetes, Lactobacilli, Bifidobacteria, Faecalibacterium, Oscillospira, Roseburia, Ruminococci, Clostridium cluster XIVa saylarının arttığını, Firmicutes ve Proteobacteria sayılarının ise azaldığını ve bu durumun KZYA ve bağırsak homeostazında artış, bağırsak disbiyozisi, patojenler ve bağırsak geçirgenliğinde ise azalmayla sonuçlandığını bildirmişlerdir. Sonuç olarak bağırsak mikrobiyotasındaki tüm bu değişiklikler oksidatif stres, inflamasyon ve kronik hastalı riskinde azalma, insülin duyarlılığı ve immün fonksiyonlarda artış ile ilişkilendirilmiştir (8). Benzer bir çalışmada ise Akdeniz diyetinin fekal KZYA, Bifidobacteria, Lactobacilli, Eubacteria, Bacteroides ve Prevotella sayılarını olumlu etkilediği, ancak inflamatuvar göstergelere bir etkisinin olmadığı gösterilmiştir (2). Akdeniz diyetinin Crohn hastalığında bağırsak miktobiyotası ve inflamatuvar göstergeler üzerindeki etkilerini inceleyen Marlow et al. (13) ise inflamatuvar göstergelerin (C-reaktif protein [CRP] gibi) azaldığını, ayrıca bağırsak mikrobiyotasını etkileyerek 
Tablo 1. Klasik Akdeniz diyetindeki farklı diyet bileşenlerinin mikrobiyota ve sağlıkla ilişkisi (8)

\begin{tabular}{|c|c|c|}
\hline Diyet bileşeni & $\begin{array}{l}\text { Sağlığa olumlu } \\
\text { etkisi }\end{array}$ & Olası mekanizmalar \\
\hline $\begin{array}{l}\text { Meyve, sebze, posa, yoğurt, } \\
\text { probiyotikler/prebiyotikler ve } \\
\text { vitaminler }\end{array}$ & $\begin{array}{l}\text { Bağırsak } \\
\text { homeostazl }\end{array}$ & $\begin{array}{l}\text { Bağırsak homeostazı, bağırsak immünitesi, KZYA ve faydalı bağırsak } \\
\text { bakterilerinde artış } \\
\text { Bağırsak geçirgenliği, fırsatçı patojenler, bağırsak ve sistemik } \\
\text { inflamasyonda azalma }\end{array}$ \\
\hline $\begin{array}{l}\text { Tam tahlllar, meyve, sebze, } \\
\text { posa, çay, polifenoller, düşük } \\
\text { glisemik indeksli besinler, } \\
\text { vitamin ve mineraller }\end{array}$ & $\begin{array}{l}\text { Karaciğer } \\
\text { hastalıkları }\end{array}$ & $\begin{array}{l}\text { Bağırsak homeostazı, bağırsak permabilitesi, KZYA ve faydalı bağırsak } \\
\text { bakterilerinde artış } \\
\text { Bağırsak disbiyozisi, bağırsak geçirgenliği, bağırsak ve sistemik } \\
\text { inflamasyon, oksidatif stres ve karaciğer toksisitesi ve inflamasyonund } \\
\text { azalma }\end{array}$ \\
\hline $\begin{array}{l}\text { Meyve, sebze, PUFA, MUFA, } \\
\text { polifenoller, C vitamini, } \\
\text { B12 vitamini, folik asit ve } \\
\text { karotenoidler }\end{array}$ & $\begin{array}{l}\text { Beyin } \\
\text { hastalıkları }\end{array}$ & $\begin{array}{l}\text { Bağırsak homeostazı, bağırsak permabilitesi, KZYA ve faydalı bağırsak } \\
\text { bakterilerinde artış } \\
\text { Bağırsak disbiyozisi, bağırsak geçirgenliği, sistemik inflamasyon, } \\
\text { bağırsak ve beyin inflamasyonunda azalma } \\
\text { Hafıza ve bilişsel fonksiyonlarda iyileşme, stres, depresyon ve } \\
\text { hipertansiyonda azalma }\end{array}$ \\
\hline $\begin{array}{l}\text { PUFA, MUFA, sert kabuklu } \\
\text { meyveler, antioksidanlar, }\end{array}$ & Astım ve alerji & $\begin{array}{l}\text { İmmün fonksiyonda artış, sistemik inflamasyon ve oksidatif streste } \\
\text { azalma }\end{array}$ \\
\hline
\end{tabular}

flavonoidler, yoğurt, tam yağlı

süt

Posa, sebze, MUFA, $\quad$ Diyabet

probiyotikler/prebiyotikler, antioksidanlar, düşük glisemik indeksli besinler, vitaminler

Posa, probiyotikler, PUFA ve MUFA

Böbrek hastalıkları

Taze meyve ve sebze, $\mathrm{C}$

Gastrik vitamini, E vitamini ve beta hastalıklar karoten

Posa, PUFA, MUFA,

Kolorektal probiyotikler, prebiyotikler, kanserler

Bağırsak homeostazı, bağırsak permabilitesi ve immünitesi, KZYA ve faydalı bağırsak bakterilerinde artış

Bağırsak geçirgenliği, endotoksemi, metabolik sendrom, sistemik düşük düzey inflamasyon ve oksidatif stresde azalma antioksidanlar, vitaminler ve polifenoller

Posa, probiyotikler, Obezite prebiyotikler, omega 3 yağ asitleri, antioksidanlar, düşük glisemik indeksli besinler, polifenoller

Bağırsak permabilitesi, KZYA ve faydalı bağırsak bakterilerinde artış Bağırsak geçirgenliği, bağırsak ve sistemik inflamasyon, proteolitik bağırsak bakterileri ve p-krizol indoksil sülfatta azalma

Gastrik homeostaz da artış, Fırsatçı patojenler, kimyasal kontaminantlar, oksidatif stres ve ülserlerde azalma İmmün fonksiyonda artış, Düşük düzey inflamasyonda ve oksidatif stresde azalma,

GLP-1: glukagon benzeri peptit-1, HDL: Yüksek dansiteli lipoprotein, IGF: Insülin benzeri büyüme faktörü, KZYA: Kısa zincirli yağ asitleri, LDL:Düşük dansiteli lipoprotein, MUFA:Tekli doymamış yağ asitleri, PUFA: Çoklu doymamış yağ asitleri, PYY: Peptit YY, VLDL:Çok düşük dansiteli lipoprotein

Bağırsak homeostazı, bağırsak permabilitesi, KZYA, faydalı bakteriler, insülin duyarlılığı, GLP-1, PYY, toklukta artış, Bağırsak geçirgenliği, açlık kan glukozu, C-peptid, IGF-1 ve oksidatif streste azalma 
Bacteroidetes ve Clostridium saylarm artıp Proteobacteria ve Bacillaceae sayılarını azaldığını göstermişlerdir (13).

Sonuç olarak Akdeniz diyetinin sağlık üzerindeki birçok olumlu etkisinin bu diyetin bağırsak mikrobiyotasında yarattığı olumlu değişikler aracılığıyla olabileceği öne sürülmektedir (2).

\section{Vejetaryen Diyet}

Vejetaryen diyetler hayvansal besinlerin kısıtlandığı veya hiç yer almadığı bitkisel kaynaklı besinlerden oldukça zengin olan diyet modelleridir (14). Akdeniz diyetinde olduğu gibi bitkisel kaynaklı beslenmenin de hayvansal kaynaklı beslenmeye göre daha düşük mortaliteyle ilişkili olduğu ve mikrobiyal sistemin daha çeşitli olmasını sağladığı görülmüştür (15).

Genel olarak vegan ve vejetaryen diyetle beslenen bireylerde Bacteroides ve Prevotella sayısı artarken, omnivor bireylerde ise Clostridium türleri artmaktadır $(16,17)$. Bu diyet modellerinde tüketimi artan posanın Ruminococcus, E. rectale, ve Roseburia gibi laktik asit bakterilerini artırdığı, Clostridium ve Enterococcus türlerini azalttığı gösterilmiştir (15). Bitkisel kaynaklı besinlerde bolbulunan polifenoller ise Bifidobacterium ve Lactobacillus türlerinde artışa neden olarak antipatojenik ve anti-inflamatuvar etki göstermektedir. Yüksek posa alımı ayrıca fermente posanın metaboliti olan KZYA üretimini artırmaktadır. Bu metabolitler patojenlere karşı immün fonksiyonların gelişmesini, kan beyin bariyerinin bütünlüğünü ve bağırsak fonksiyonlarının düzenlenmesini sağlamaktadır (15). Bunlara ek olarak bitkisel kaynaklı protein tüketimindeki artış ile birlikte de KZYA, Bifidobacterium ve Lactobacillus seviyelerinde artışı sağlamakla beraber, Clostridium ve Bacteroides'in patojenik bakteri türlerinde azalmaya neden olduğu görülmüştür (9).

Vegandiyetlebeslenenlerdebağırsakmikrobiyotasında çeşitliliğin arttığı ve özellikle polifenolik bileşenlerden gelen bağırsak metabolitlerinin de fazla olduğu gösterilmiştir (14).

\section{Yüksek Proteinli Diyetler}

Yüksek proteinli diyetler toplam enerjinin \%2530'nun proteinden geldiği diyetlerdir (18). Yüksek proteinli diyetlerin vücut ağırlık kaybındaki olası olumlu etkilerinin yanı sıra mikrobiyota üzerine etkisi de tartışılmaktadır. Hem hayvansal kaynaklı (et, yumurta, peynir) hem de bitkisel kaynaklı proteinlerin (sebze, meyve, tahıl, baklagiller) mikrobiyal çeşitlilikle pozitif ilişkili olduğu gösterilmiştir $(5,12)$. David et al. (5) hayvansal kaynaklı protein (enerjinin \%30.1'i) içeren posasız beş günlük beslenme planının Alistipes, Bilophila ve Bacteroides sayısını artırdığı, bitkisel kaynaklı polisakkaritleri metabolize eden Firmicutes (Roseburia, Eubacterium rectale ve Ruminococcus) sayısını azalttığını göstermişlerdir. Ayrıca yüksek proteinli diyetin iki gün içerisinde mikrobiyota çeşitliliğini değiştirdiği ancak bu değişikliğin geçici olduğu ve müdahaleden sonra 2 gün içerinde eski haline döndüğü rapor edilmiştir (5). Yüksek proteinli diyetlerin bir diğer etkisi de izobütirat, izovalerat ve 2-metilbütirat gibi amino asit türevli KZYA'lerini artırmasıdır. Ancak bu diyetlerin bütirat seviyesinde azalmaya neden olduğu gösterilmiştir (18). Bütirat substratlar için enerji kaynağı ve hızla yenilenen kolon epitel hücrelerinde gen ekspresyonunun bir regülatörü olarak kabul edildiğinden, bu düşüşün kolonik mukoza homeostazı için potansiyel olarak zararlı olduğu düşünülmektedir (18).

Ayrıca bu diyet, bağırsak mukozasının, kolonositlere karşı genotoksik ve metabolik sorun oluşturan bakteriyel bir metabolit olan p-krizole daha fazla maruz kalmasına neden olur. Aynı zamanda p-krizol renal hücreler için toksik etki oluşturan p-krezil sülfatında öncü maddesidir (19). Ancak tam tersine yüksek proteinli diyetler, kalın bağırsak mukozasının, epitel bariyer fonksiyonunun korunmasında önemli bir rolü olan ve bakteriyel bir metabolit olan indol seviyesini artırır. Bağırsak epiteli üzerinde olumlu etki gösteren indolün bir metaboliti olan indoksil sülfat ise toksik etki göstermektedir (18).

Yüksek proteinli diyetlerde hem dirençli nişasta hem de toplam karbonhidrat miktarı düşüktür (20). Özelikle 
dirençli nişasta Bifidobacterium ve Eubacterium spp. varlığı ile pozitif ilişkilidir. Yüksek proteinli diyetlerin, enerji kısıtlaması veya posa alımıyla ilgili düzenleme olmadığında bağırsak mikrobiyotası üzerine sinırlı etkisinin olduğu görülmektedir (18).

\section{FODMAP Diyet}

Fermente oligosakkaritler, disakkaritler, monosakkaritler ve polyollerin (FODMAP) kısıtlandığı diyet modelinin inflamatuvar bağırsak sendromu (İBS) semptomlarının düzenlenmesinde etkili olduğu bilinmektedir (21,22). Bu karbonhidratların büyük kısmı tamamlanmayan hidroliz veya absorbsiyondan dolayı kolona ulaşmakta, ince bağırsak volümünü artırarak abdominal ağrı ve şişkinliği artırabileceği gibi luminal distansiyona neden olan kolonik hidrojen ve metan üretimini de arttırdığından İBS'de sınırlandırılmaktadır. İnflamatuvar bağırsak sendromunda önerilen düşük FODMAP içeren diyet 5-18 g/gün FODMAP içermektedir $(21,22)$.

Yapılan bir çalışmada, İBS hastalarına 3 hafta uygulanan düşük FODMAP tedavisinden sonra bakteri konsantrasyonunun (özellikle Bifidobacteria konsantrasyonu) ve toplam bakteri yükünün \%47 oranında azaldığı gösterilmiştir (21). Ayrıca 3 haftanın sonunda bütirat üreten Clostridium cluster XIVa türünde azalma olduğu görülmüş, ancak fekal KZYA konsantrasyonunda bir değişiklik gözlemlenmemiştir (21). Benzer olarak Staudacher et al. (23) tarafindan yapılan bir çalışmada İBS hastalarında 4 hafta boyunca uygulanan düşük FODMAP diyeti sonrasında Bifidobacteria konsantrasyonlarının daha düşük ancak İBS semptomlarının daha iyi olduğu görülmüştür.

Düşük FODMAP içeren diyetin bir diğer özelliği de prebiyotik alımını \%50’ye kadar azaltmasıdır (22). Özellikle oligosakkaritlerin sağlıklı bireylerde kolonik mikrobiyota üzerine pozitif etkilerinin olduğu bilindiğinden düşük FODMAP diyetin kolon sağlığını olumsuz etkileyebileceği de düşünülmektedir. Bu nedenle asemptomatik popülasyonlara önerilmemesi gerektiği, uzun dönem uygulamalarında dikkatli olunması gerektiği vurgulanmaktadır (21).
Ooi et al. (24), 2013-2018 yıllarında yayınlanan sistemik derleme ve meta analizleri inceledikleri çalışmada düşük FODMAP içeren diyetin İBS semptomlarına (abdominal ağrı, şişkinlik, gibi) iyi geldiğini rapor etmişlerdir. Ancak uygun olmayan düşük FODMAP diyetin kullanımının sağllk için olumsuz etki gösterebileceği vurgulanmıştır. FODMAP dışında diğer tetikleyici unsurların da (alkol, baharatlı besinler, yüksek yağlı besinler gibi) İBS'de alımının kontrol altına alınması gerekmektedir (24). Uzun dönemde daha geniş örneklem grubuyla özellikle mikrobiyota üzerine etkilerini de inceleyerek yapılacak çalışmalara ihtiyaç vardır.

\section{Glutensiz Diyet}

Glutensiz diyet; buğday, arpa ve çavdar gibi gluten içeren kaynakların diyetten çıkarılmasıyla oluşturulan bir diyet olup, çölyak hastalığı, gluten intolerası gibi gluten ile ilişkili hastalıklarda terapötik bir yaklaşımdır. Ancak günümüzde, sağlığın korunması, vücut ağırlığı kaybı ve/veya gelecekteki gastrointestinal hastalık riskini azaltması konusunda bilimsel dayanağı olmayan faydaları nedeniyle glutensiz diyet popüler hale gelmiştir (25).

Yeni tanı alan çölyak hastalarının mikrobiyotalarının dengesiz olduğu görülmüştür. Bifidobacterium, B. longum ve Lactobacillus spp. türünün azaldığı, Enterobacteriaceae spp. gibi birçok zararlı bakterinin arttığı gösterilmiştir. Ayrıca birçok mikrobiyal türün fazlalığı çölyak hastalığıyla ilişkilendirilmiştir (26,27). Çölyak hastalarının intestinal mikrobiyotalarında sağlıklı bireylere göre daha az tür bulunduğu tespit edilmiştir (25).

Çölyak hastalarında uygulanan glutensiz diyet, yararlı bakteri sayısının arttırılmasına ve zararlı mikrobiyal türlerin sayısının azaltılmasına katkıda bulunarak bağırsak ekosisteminin iyileşmesini sağlar. Ancak mikrobiyotanın düzenlenmesinin, çölyak hastalarında sağlık durumunu iyileştirme ihtimali araştırılması gereken bir noktadır (27).

Çölyak hastalıklarında tedavinin bir parçası olan glutensiz diyet tüketimi bağırsak mikrobiyotasında 
iyileşme sağlayabilirken, sağlıklı bireylerde bu diyetin uygulanması ise farklı etki göstermektedir. Glutensiz diyette bağırsak kompozisyonundaki değişikliklerin polisakkarit alımının azalmasıyla ilişkili olabileceği düşünülmektedir. Bu makro besin ögeleri genellikle kolonun kısmen sindirilmeyen distal kısmına ulaşır ve bağırsak mikrobiyotasındaki türlere enerji sağlar. Bu nedenle azalan polisakkarit alımı, mikrobiyal türlerin substrat için yarışmasına ve firsatçı patojenlerin artmasına, ayrıca polisakkarit seviyesindeki azalma KZYA konsantrasyonunun azalmasina neden olmaktadır. Ancak diyet posasının artırılması KZYA seviyesinde artışı sağlayabilir (27). On sağlıklı bireyin glutensiz diyeti 30 gün uygulamadan sonra polisakkarit alımındaki azalmaya bağlı olarak yararlı bakterilerin (Bifidobacterium ve Lactobacillus) azaldı̆̆ı, patojen bakterilerin arttığı görülmüştür (28). Mikrobiyotadaki disbiyoz, remisyonda ve glutensiz diyeti uygulayan hastalarda tam bir iyileşme sağlanana kadar devam eder. Sağllklı bireylerde ise bir aydan uzun süre uygulanan glutensiz diyetin bağırsak için faydalı bakteri popülasyonunda azalmaya neden olduğu gösterilmiştir (25).

\section{Düşük Karbonhidrat İçeren Diyetler}

Karbonhidratlar, özellikle sindirilmeyen karbonhidratların (posa ve dirençli nişasta gibi) bağırsak mikrobiyota kompozisyonu, çeşitliliği ve metabolik profili üzerine etkisi fazladır. Ayrıca bu karbonhidratlar prebiyotik etki gösterebileceğinden Bifidobacterium ve laktik asit bakterileri gibi bakterilerin aktivitesini düzenleyebilmektedir (9). Günümüzde düşük karbonhidrat içeren diyetler (<\%40 enerji) vücut ağırlığı kontrolü ve sağlık göstergelerinin iyileşmesinde kullanılan diyet modelleri arasında yer almaktadır. Yüksek posa içeren diyet, faydalı bakteri olan Bifidobacterium longum, Bifidobacterium breve ve Bifidobacterium thetaiotaomicron gibi Bifidobacteria'lerin seviyelerinde artışa, Mycobacterium avium spp. ve Enterobacteriaceae gibi firsatçı patojenlerde azalmaya neden olurken (29); düşük karbonhidrat içeren diyetler Collinsella aerofaciens ve E. Rectale sayısını anlaml olarak azaltmaktadir (20).
Duncan et al. (30) 19 obez sağlıklı bireye üç farklı diyeti (yüksek karbonhidrat (399 g/gün) içeren diyet, yüksek protein orta düzey karbonhidrat (164 g/gün) içeren diyet, yüksek protein düşük karbonhidrat (24 g/gün) içeren diyet) 4 hafta boyunca uygulamışlardır. Çalışma sonunda karbonhidrat miktarı azaldıkça başta bütirat olmak üzere KZYA'da azalma olduğu, Bacteroides, Clostridium XIVa, IX veya IV sayllarında belirgin bir değişiklik olmadığı ve Roseburia spp., E. rectale ve Bifidobacteria sayısının da düştüğünü gözlemlemişlerdir (30). Fermente karbonhidratların bütirat üretimiyle doğrudan ilişkili olmasinın bu sonuca yol açtığı düşünülmektedir.

Günlük karbonhidrat alımını 50 g’ın altına indiren ve otizm, multipl skleroz ve infantil dirençli epilepsi hastalıklarında kullanılan ketojenik diyet modelinin (1) ise mikrobiyotaya etkisi ile ilgili çok fazla bilgi bulunmamaktadır. Ketojenik diyet uygulayan epilepsili infantlarda nöbet siklığının azaldığı, Bacteroides ve Prevotella artarken, Cronobacter seviyesinin yaklaşık \%50 oranında azalarak bağırsak mikrobiyota kompozisyonunun sağlıklı kontrol grubuna doğru değiştiği gösterilmiştir (31).

Düşük karbonhidrat içeren diyetlerin mutlaka doktor ve diyetisyen gözetiminde kullanılması gerektiği unutulmamalıdır. Bağırsak mikrobiyotasını etkileyen bu diyetlerin uzun süre kullanımıyla ilgili yapılacak daha fazla çalışmaya ihtiyaç vardır.

\section{Batı Tarzı Diyetler}

Batı tarzı diyetler; hayvansal kaynaklı besinlerin (doymuş yağlar), yumurta, rafine karbonhidrat ve toplam yağın yüksek miktarda; meyve ile sebze (posa ve mikro besin ögeleri) ve tam tahilların daha az tüketilmesini kapsayan diyetlerdir (32). $\mathrm{Bu}$ diyetler bağırsak mikrobiyotasında disbiyozisle ilişkili olarak obezite, metabolik sendrom, Tip 2 DM ve kardiyovasküler hastalıklar gibi birçok kronik hastalıkla ilişkilendirilmektedir (8).

Batı tarzı diyetin , toplam bakteri sayısı ve bakteri çeşitliliğini azalttığı, faydalı bakterilerden olan Bifidobacterium ve Eubacterium türlerini azalttığı 
gösterilmiştir (9,12). Batı tarzı diyetin insanda kolorektal karsinom gelişimiyle Fusobacterium nucleatum miktarındaki artış ile ilişkili olduğu bulunmuştur. Sadece iki hafta süresince yüksek yağ (enerjinin \%52'si), düşük posa (12 g/gün) içeren batı tarzı diyetten sonra Fusobacterium nucleatum'un arttığı görülmüştür (33).

Batı tarzı diyetin içerdiği yüksek yağ nedeniyle anaerobik mikroflora ve Bacteriodes sayısını artırdığı gösterilmiştir (12). Fava et al. (11) farklı miktarlarda diyet yağları ile mikrobiyota arasındaki ilişkiyi inceledikleri çalışmada; düşük yağ tüketiminin fekal Bifidobacterium da artışa, yüksek doymuş yağ tüketiminin ise Faecalibacterium prausnitzii miktarında artışa neden olduğu görülmüştür. Ayrıca yüksek tekli doymamış yağ tüketen bireylerde, herhangi bir bakteri türünün nispi bolluğunda kayma yaşanmamış, ancak toplam bakteri yükünde azalma olduğu görülmüştür (11).

Wu et al. (17) hayvansal kaynaklı protein ve doymuş yağ asidi tüketimiyle Bacteroides sayısının; yüksek karbonhidrat ve basit şeker tüketimiyle ise Prevotella sayısının yüksek ilişkili olduğunu göstermişlerdir. Bunlara ek olarak hayvansal kaynaklı beslenmeyi temel alan diyetlerle beslenenlerin bağırsak mikrobiyotasında Bilophila wadsworthia varlığında ve aktivitesinde artış gözlemlenirken bu durumun inflamatuvar bağırsak hastalığını aktive edebileceğine dikkat çekilmiştir (5).

Farklı diyet modellerinin bağırsak mikrobiyotası üzerine farklı etkileri olabilmektedir. Popüler diyetlerin intestinal mikrobiyota ve kardiyometabolik hastalıklar üzerine etkisi Şekil 1'de gösterilmiştir (12).

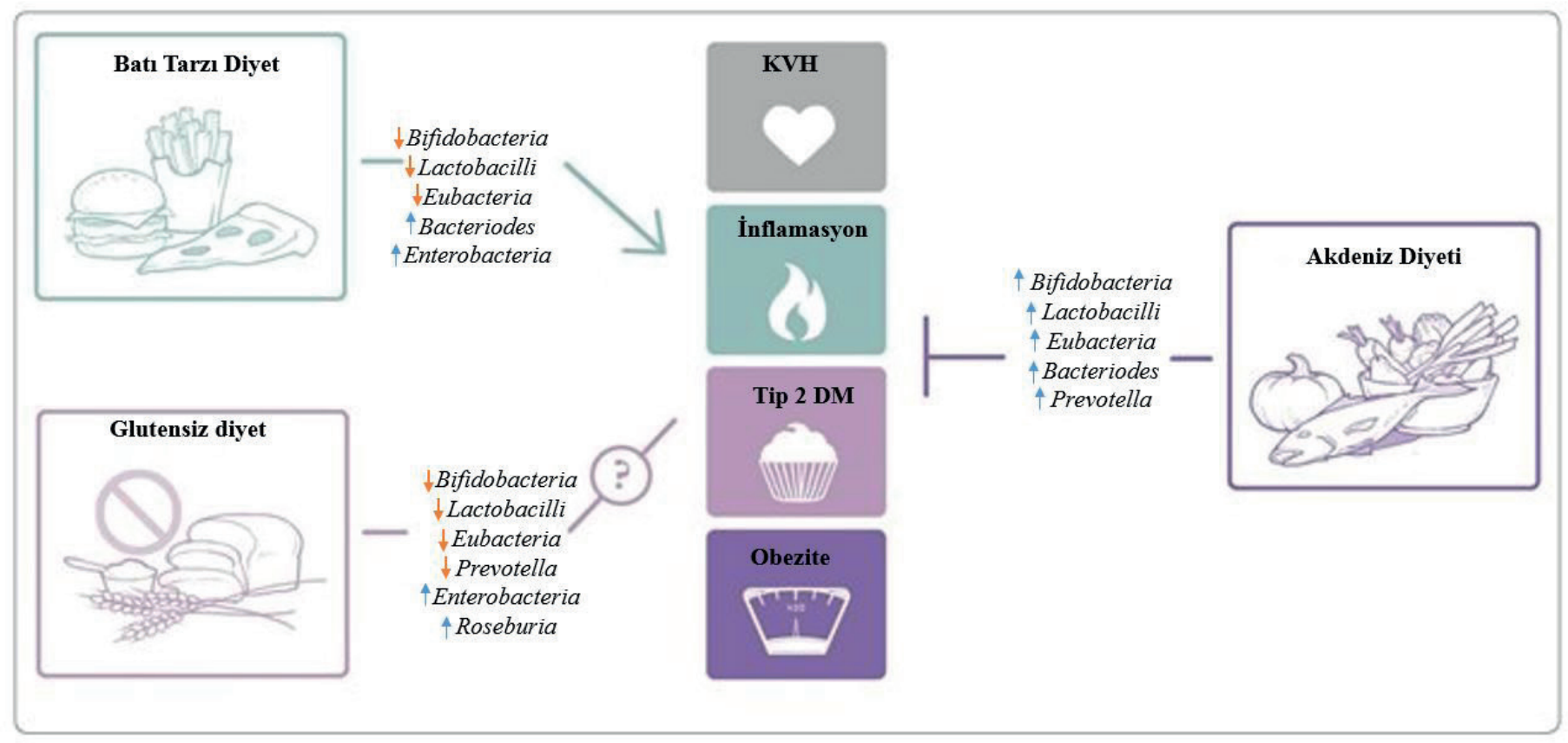

Şekil 1. Popüler diyetlerin intestinal mikrobiyota ve kardiyometabolik hastalıklar üzerine etkisi (12)

(KVH: Kardiyovasküler hastalık; Tip 2 DM: Tip 2 diyabet)

\section{Açlık Diyetleri}

Açlık diyet modeli, belirli bir süre boyunca tüm yiyeceklerden uzak durma şeklinde oluşan bir diyet türüdür. Açlık diyetlerinin vücut ağırlığı kaybının yanı sıra sağlık için faydalarının üzerinde durulmaktadır (34). Bu diyetlerin bağırsak mikrobiyotası üzerinde etkili olduğu düşünülmektedir (35). Bağırsak mikrobiyomu, konak ile simbiyotik bir ilişkiye sahip olup sindirilmeyen besinleri sindirerek sekonder 
metabolit oluştururlar. Bu metabolitler konağın uzun süren açlıkta fizyolojisini etkileyebilir ve endojen substratları metabolize edebilmektedir (35).

Gün aşırı yapılan açlık diyetinin farelerde Firmicutes sayısının artmasına neden olduğu ve Firmicutes/ Bacteriodes oranını artırdığı gözlemlenmiştir (36). Ayrıca bu diyetin bej yağ dokusunu bağırsak mikrobiyotasındaki değişiklikle aktive edebileceği bildirilmiştir (36). Açlığın patojenik Proteobacteria sayısını azaltırken faydalı Akkermansia muciniphila sayısını artırdığını gösteren çalışmalarda vardır (37).

Sonuç olarak açlık diyetlerinin olumlu etkilerinin mikrobiyota aracılığıyla da gelişebileceği düşünülmektedir ancak faydaları üzerine net bir bilgiye rastlanılmamıştır. $\mathrm{Bu}$ nedenle insanlar üzerinde yapılan geniş örneklemli uzun dönem çalışmalara ihtiyaç vardır.

\section{Paleolitik/Paleo Diyet}

Taş devri olarak da adlandırılan diyet modeli olup farklı türleri bulunmaktadır. Sebze, meyve ve baharatların fazla, yağsız etlerin orta/yüksek miktarda, organ etleri, balık ve yumurta, orta seviyede yağlı tohum ve sert kabuklu meyvelerin tüketildiği, tüm işlenmiş besinlerin, baklagiller, tahıllar, süt ve ürünleri ve bitkisel yağların (zeytinyağı ve hindistan cevizi yağı dışında) yasaklandığı modern paleolitik diyet bunlardan biridir (1).

Tahılların insan diyetine dahil edilmesinde yaklaşık 10.000 yıl önce başladığı düşünülmektedir. Bu nedenle insan bağırsağının veya mikrobiyotanın bu şiddetli diyet değişikliklerine uygun bir şekilde adapte olmadığı bundan dolayı tahıl tüketilmemesi gerektiği savunulmaktadır $(16,38)$. Glutenle tanışmadan önceki mikrobiyotayı yansitacağı düşünülen Tanzanya'da bulunan Hadza avcılarının (et tüketiminin fazla, tarım ürünlerinin en az düzeyde tüketildiği [enerjinin $\% 5$ 'inden az] diyetle beslenen) fekal analizleri ve İtalya'da Akdeniz diyetiyle beslenen bireyler kıyaslandığında Hadza yerlilerinin mikrobiyal zenginlik ve çeşitliliğinin İtalyanlara göre daha fazla olduğu görülmüştür. Hadza mikrobiyotasında
Firmicutes (72\%), Bacteroidetes (17\%), Proteobacteria (6\%) ve Spirochaetes (3\%) bakterileri bulunmasina rağmen probiyotik olarak da kullanılan Bifidobacteria'ya rastlanılmamıştır (38).

Barone et al. (39) ise, 15 İtalyan bireye (3 kadın, 12 erkek) Paleo diyet (işlenmemiş ürünlerin yer aldığı, tahıl, süt ve ürünleri, tuz ve rafine şekerin çıkarıldığı diyet) vererek takip etmişler ve çalışma sonunda Paleo diyetle bakteriyel çeşitliliğin arttığını gözlemlemişlerdir (39). Ancak Paleo diyetinin etkisini modern zamanda yaşayan insanların genetiği ve çevresel koşullarını da gözeterek yapılacak uzun dönem çalışma sonuçlarına göre değerlendirmek gerekmektedir.

\section{SONUÇ VE ÖNERİLER}

Farklı diyet modellerinin içerdikleri besin çeşitliliği ve farklı oranlardaki besin ögesi konsantrasyonları göz önüne alındığında, bu diyet modellerinin bağırsak mikrobiyotasını etkilemesinin yanı sıra insan sağlığını ve kronik hastalıkları farklı şekilde etkileyebileceği düşünülmektedir. Bu diyet modellerinin bağırsak mikrobiyotası üzerindeki etkileri bilimsel olarak netlik kazanmadığından, bireye özgü enerji ve besin ögesi gereksinmelerini karşılayacak yeterli ve dengeli beslenme sağlığın korunmasında oldukça önemlidir. Ancak sadece kişinin beslenme tarzı değil aynı zamanda yaşı, cinsiyeti, genetik özellikleri, fiziksel aktivite düzeyi, alkol ve sigara kullanımı gibi birçok faktörün de bağırsak mikrobiyatasını etkileyebileceği unutulmamalıdir. r.

Çıkar çatışması - Conflict of interest: Yazarlar çıkar çatışması olmadığını beyan ederler. - The authors declare that they have no conflict of interest.

\section{KAYNAKLAR}

1. Klement RJ, Pazienza V. Impact of different types of diet on gut microbiota profiles and cancer prevention and treatment. Medicina. 2019;55(4):84.

2. Del Chierico F, Vernocchi P, Dallapiccola B, Putignani L. Mediterranean diet and health: food effects on gut microbiota and disease control Int J Mol Sci. 2014;15(7):11678-99. 
3. Zhang C, Zhang M, Wang S, Han R, Cao Y, Hua W, et al. Interactions between gut microbiota, host genetics and diet relevant to development of metabolic syndromes in mice. ISME J. 2009;4:232-41.

4. Tremaroli V, Bäckhed F. Functional interactions between the gut microbiota and host metabolism. Nature. 2012;489(7415):242-9.

5. David LA, Maurice CF, Carmody RN, Gootenberg $\mathrm{DB}$, Button JE, Wolfe BE, et al. Diet rapidly and reproducibly alters the human gut microbiome. Nature. 2014;505(7484):559-63.

6. De Filippo C, Cavalieri D, Di Paola M, Ramazzotti M, Poullet JB, Massart S, et al. Impact of diet in shaping gut microbiota revealed by a comparative study in children from Europe and rural Africa. Proc Natl Acad Sci USA. 2010;107(33):14691-6.

7. Dernini S, Berry EM. Mediterranean diet: from a healthy diet to a sustainable dietary pattern. Front Nutr. 2015;2:15.

8. Nagpal R, Shively CA, Register TC, Craft S, Yadav H. Gut microbiome-Mediterranean diet interactions in improving host health. F1000Research. 2019;8:699.

9. Garcia-Mantrana I, Selma-Royo M, Alcantara C, Collado MC. Shifts on gut microbiota associated to Mediterranean diet adherence and specific dietary intakes on general adult population. Front Microbiol. 2018;9:890.

10. De Filippis F, Pellegrini N, Vannini L, Jeffery IB, La Storia A, Laghi L, et al. High-level adherence to a Mediterranean diet beneficially impacts the gut microbiota and associated metabolome. Gut. 2016;65(11):1812-21.

11. Fava F, Gitau R, Griffin B, Gibson G, Tuohy K, Lovegrove $\mathrm{J}$. The type and quantity of dietary fat and carbohydrate alter faecal microbiome and short-chain fatty acid excretion in a metabolic syndrome 'at-risk'population. Int J Obes. 2013;37(2):216-23.

12. Singh RK, Chang H-W, Yan D, Lee KM, Ucmak D, Wong $\mathrm{K}$, et al. Influence of diet on the gut microbiome and implications for human health. J Transl Med. 2017;15(1):73.

13. Marlow G, Ellett S, Ferguson IR, Zhu S, Karunasinghe N, Jesuthasan AC, et al. Transcriptomics to study the effect of a Mediterranean-inspired diet on inflammation in Crohn's disease patients. Hum Genomics. 2013;7(1):24.

14. Wu GD, Compher C, Chen EZ, Smith SA, Shah RD, Bittinger $\mathrm{K}$, et al. Comparative metabolomics in vegans and omnivores reveal constraints on diet-dependent gut microbiota metabolite production. Gut. 2016;65(1):6372.

15. Tomova A, Bukovsky I, Rembert E, Yonas W, Alwarith J, Barnard ND, et al. The effects of vegetarian and vegan diets on gut microbiota. Front Nutr. 2019;6:47.

16. Costabile A, Klinder A, Fava F, Napolitano A, Fogliano
V, Leonard C, et al. Whole-grain wheat breakfast cereal has a prebiotic effect on the human gut microbiota: a double-blind, placebo-controlled, crossover study. Br J Nutr. 2008;99(1):110-20.

17. Wu GD, Chen J, Hoffmann C, Bittinger K, Chen Y-Y, Keilbaugh SA, et al. Linking long-term dietary patterns with gut microbial enterotypes. Science. 2011;334(6052):105-8.

18. Blachier F, Beaumont M, Portune KJ, Steuer N, Lan A, Audebert M, et al. High-protein diets for weight management: Interactions with the intestinal microbiota and consequences for gut health. A position paper by the my new gut study group. Clin Nutr. 2019;38(3):1012-22.

19. Andriamihaja M, Lan A, Beaumont M, Audebert M, Wong X, Yamada K, et al. The deleterious metabolic and genotoxic effects of the bacterial metabolite p-cresol on colonic epithelial cells. Free Radic Biol Med. 2015;85:21927.

20. Walker AW, Ince J, Duncan SH, Webster LM, Holtrop $\mathrm{G}, \mathrm{Ze} \mathrm{X}$, et al. Dominant and diet-responsive groups of bacteria within the human colonic microbiota. ISME J. 2011;5(2):220-30.

21. Halmos EP, Christophersen CT, Bird AR, Shepherd SJ, Gibson PR, Muir JG. Diets that differ in their FODMAP content alter the colonic luminal microenvironment. Gut. 2015;64(1):93-100.

22. Böhn L, Störsrud S, Liljebo T, Collin L, Lindfors P, Törnblom $\mathrm{H}$, et al. Diet low in FODMAPs reduces symptoms of irritable bowel syndrome as well as traditional dietary advice: a randomized controlled trial. Gastroenterology. 2015;149(6):1399-407.

23. Staudacher HM, Lomer MC, Anderson JL, Barrett JS, Muir JG, Irving PM, et al. Fermentable carbohydrate restriction reduces luminal bifidobacteria and gastrointestinal symptoms in patients with irritable bowel syndrome. J Nutr. 2012;142(8):1510-8.

24. Ooi SL, Correa D, Pak SC. Probiotics, prebiotics, and low FODMAP diet for irritable bowel syndrome-What is the current evidence? Complement Ther Med. 2019;43:73-8.

25. Gobbetti M, Pontonio E, Filannino P, Rizzello CG, De Angelis M, Di Cagno R. How to improve the gluten-free diet: The state of the art from a food science perspective Food Res Int. 2018;110:22-32.

26. Cenit M, Olivares M, Codoñer-Franch P, Sanz Y. Intestinal microbiota and celiac disease: cause, consequence or co-evolution? Nutrients. 2015;7(8):6900-23.

27. Melini V, Melini F. Gluten-Free Diet: Gaps and Needs for a Healthier Diet. Nutrients. 2019;11(1):170.

28. Sanz Y. Effects of a gluten-free diet on gut microbiota and immune function in healthy adult humans. Gut Microbes. 2010;1(3):135-7.

29. Pokusaeva K, Fitzgerald GF, van Sinderen D. 
Carbohydrate metabolism in Bifidobacteria. Genes Nutr. 2011;6(3):285-306.

30. Duncan SH, Belenguer A, Holtrop G, Johnstone AM, Flint HJ, Lobley GE. Reduced dietary intake of carbohydrates by obese subjects results in decreased concentrations of butyrate and butyrate-producing bacteria in feces. Appl Environ Microbiol. 2007;73(4):1073-8.

31. Xie G, Zhou Q, Qiu C-Z, Dai W-K, Wang H-P, Li Y-H, et al. Ketogenic diet poses a significant effect on imbalanced gut microbiota in infants with refractory epilepsy. World J Gastroenterol. 2017;23(33):6164-71.

32. Lairon D. Intervention studies on Mediterranean diet and cardiovascular risk. Mol Nutr Food Res.. 2007;51(10):1209-14.

33. O’Keefe SJ, Li JV, Lahti L, Ou J, Carbonero F, Mohammed $\mathrm{K}$, et al. Fat, fibre and cancer risk in African Americans and rural Africans. Nat Commun. 2015;6:6342.

34. Mattson MP, Allison DB, Fontana L, Harvie M, Longo VD, Malaisse WJ, et al. Meal frequency and timing in health and disease. PNAS. 2014;111(47):16647-53.

35. Beli E, Yan Y, Moldovan L, Vieira CP, Gao R, Duan Y, et al. Restructuring of the gut microbiome by intermittent fasting prevents retinopathy and prolongs survival in db/db mice. Diabetes. 2018;67(9):1867-79.

36. Li G, Xie C, Lu S, Nichols RG, Tian Y, Li L, et al. Intermittent fasting promotes white adipose browning and decreases obesity by shaping the gut microbiota. Cell Metab. 2017;26(5):801.

37. Zheng X, Zhou K, Zhang Y, Han X, Zhao A, Liu J, et al. Food withdrawal alters the gut microbiota and metabolome in mice.FASEB J. 2018;32(9):4878-88.

38. Schnorr SL, Candela M, Rampelli S, Centanni M, Consolandi C, Basaglia G, et al. Gut microbiome of the Hadza hunter-gatherers. Nat Commun. 2014;5:3654.

39. Barone M, Turroni S, Rampelli S, Soverini M, D’Amico F, Biagi E, et al. Gut microbiome response to a modern Paleolithic diet in a Western lifestyle context. Plos One. 2019;8(14)8:e0220619. 